\title{
TAINACANTHUS FEROX, A REMARKABLE NEW GENUS AND SPECIES OF KATYDIDS FROM THE HIGH MOUNTAINS OF HISPANIOLA (ORTHOPTERA: TETTIGONIIDAE: PSEUDOPHYLLINAE: POLYANCISTRINI)
}

\section{Tainacanthus ferox, un excepcional nuevo género y especie de esperanzas de las altas montañas de la Hispaniola (Orthoptera: Tettigoniidae: Pseudophyllinae: Polyancistrini)}

\author{
Daniel E. Perez-Gelabert
}

Integrated Taxonomic Information System (ITIS) and Department of Entomology, National Museum of Natural History, Smithsonian Institution, P.O. Box 37012, Washington, DC 20013-7012, USA; perezd@si.edu. (i) orcid.org/0000-0003-3270-9551.

\section{ABSTRACT}

The new genus and species of Polyancistrini katydids Tainacanthus ferox gen. nov., sp. nov. is described from specimens collected in the highest mountains of the Dominican Republic, island of Hispaniola. This is the third genus of Polyancistrini known from Hispaniola and the seventh genus of the tribe. Tainacanthus is distinctive due to the unique architecture of its pronotum, which is a large and bulbous shield with an extended metazona that covers and protects the stridulatory apparatus surrounded by a relatively small number of large and sharp spines. Additionally, all legs are armed with larger and more robust spines than those of Polyancistrus Audinet-Serville, 1831, its most likely closest relative. Tainacanthus inhabits the highest mountains of the Dominican Cordillera Central at over 2,400 $\mathrm{m}$ above sea level, living among hard-leaf evergreen vegetation interspersed with pine forests. The type locality is included within the Armando Bermúdez National Park, one of the most important protected areas in the Dominican Republic.

Keywords: Tettigonioidea, taxonomy, biodiversity, distribution, Greater Antilles, West Indies.

\section{RESUMEN}

Se describe el nuevo género y especie de esperanzas Polyancistrini Tainacanthus ferox gen. nov. sp. nov., a partir de especímenes colectados en las montañas más altas de la República Dominicana, isla de la Hispaniola. Tainacanthus es el tercer género conocido de Polyancistrini de la Hispaniola y el séptimo género de la tribu. Tainacanthus se distingue por la arquitectura única de su pronoto, el cual es un escudo grande y bulboso con metazona extendida que cubre y protege el aparato estridulador, rodeado por unas pocas espinas grandes y puntiagudas. Adicionalmente, todas sus patas son armadas con espinas más grandes y robustas que en Polyancistrus Audinet-Serville, 1831, su probable pariente más cercano. Tainacanthus habita las montañas más altas de la Cordillera Central Dominicana por encima de 2,400 $\mathrm{m}$ sobre el nivel del mar, viviendo entre vegetación perenne de hojas gruesas entremezclada con bosques de pino. La localidad tipo se incluye dentro del Parque Nacional Armando Bermúdez, una de las áreas protegidas más importantes de República Dominicana. 


\section{INTRODUCTION}

The Pseudophyllinae with just over one thousand species are the second most diverse group of katydids after the Phaneropterinae (Gwynne, 2001). These katydids are differentiated from other subfamilies of Tettigoniidae by having front tibiae without terminal spines above, an open auditory tympanum and antennal scrobes or pits with the margins raised or produced (Bruner, 1915). Pseudophyllines are predominantly found in tropical habitats and appear to be most diverse in the New World tropics. Although usually large, morphologically they encompass a variety of forms and colorations, including species that mimic leaves, bark or other background, also including brachypterous species with reduced wings (Gwynne, 2001). The Orthoptera Species File online database (Cigliano et al., 2018) includes 20 tribes within the Pseudophyllinae. The tribe Polyancistrini Brunner von Wattenwyl, 1878 are medium-sized to large $(25-50 \mathrm{~mm})$ and heavy katydids, characterized by having a robust body, most often with markedly reduced wings and a pronotum that extends over the base of the tegminae in both sexes.

Hitherto this tribe was comprised of six genera: Polyancistrus Audinet-Serville, 1831 and Spelaeala Rehn, 1943 from Hispaniola, Sagephorus Redtenbacher, 1895 from Mexico, Polyancistroides Rehn, 1901 from Cuba, Camposiella Hebard, 1924 from Ecuador, and Spinapecta Naskrecki \& Lopes-Andrade, 2005, from Brazil. Tainacanthus gen. nov. like Spelaeala and most of the species of Polyancistrus has very reduced scale-like or lobate tegminae that form a bulbous stridulatory apparatus covered by a shield-like expansion of the pronotum in both sexes. Tainacanthus gen. nov. is endemic to the high mountains (over 2,400 m above sea level) of the Cordillera Central of Hispaniola. A list of the Greater Antillean species is shown in Table I.

The first Hispaniolan Polyancistrini was described by Palisot de Beauvois (1805) as Locusta serrulata, later transferred to the newly proposed genus Polyancistrus Audinet-Serville (1831). The genus Polyancistrus was reviewed by Rehn (1936) using a sample of 79 specimens from Haiti and the Dominican Republic gathered from various North American museum collections. Rehn (1936) described five additional species, most of them having marked wing reduction. Subsequently, Rehn (1943) described the smaller and nearly apterous genus Spelaeala, based on a small series of seven specimens that included two species, both also from the Cordillera Central of the Dominican Republic. The most recent addition to the Polyancistrini is the genus Spinapecta from southeastern Brazil (Naskrecki \& Lopes-Andrade, 2005), which significantly expanded the geographical range of the tribe.

In this paper, I describe and illustrate the seventh known genus of the tribe Polyancistrini and the third known from the Caribbean island of Hispaniola. Comments are included on its song, together with observations on its habitat and behavior.

\section{OBJECTIVE}

- To provide the taxonomic description of a new genus and species of Polyancistrini katydids from high mountain localities in the Dominican Republic. 
Table I. List of the Greater Antillean Polyancistrini species

\begin{tabular}{|c|c|c|}
\hline Species & Island & References \\
\hline \multicolumn{3}{|l|}{ Genus Polyancistrus Audinet-Serville, 1831} \\
\hline $\begin{array}{l}\text { Polyancistrus serrulatus serrulatus } \\
\text { (Palisot de Beauvois, 1805) }\end{array}$ & Hispaniola & Rehn (1936) \\
\hline Polyancistrus serrulatus oreiotes Rehn, 1936 & Hispaniola & Rehn (1936) \\
\hline Polyancistrus atlas atlas Rehn, 1936 & Hispaniola & Rehn (1936) \\
\hline Polyancistrus atlas pilanus Rehn, 1936 & Hispaniola & Rehn (1936) \\
\hline Polyancistrus loripes Rehn, 1936 & Hispaniola & Rehn (1936) \\
\hline Polyancistrus darlingtoni Rehn, 1936 & Hispaniola & Rehn (1936) \\
\hline Polyancistrus abbotti Rehn, 1936 & Hispaniola & Rehn (1936) \\
\hline Polyancistrus gerulus Rehn, 1936 & Hispaniola & Rehn (1936) \\
\hline \multicolumn{3}{|l|}{ Genus Spelaeala Rehn, 1943} \\
\hline Spelaeala bondi Rehn, 1943 & Hispaniola & Rehn (1943) \\
\hline Spelaeala scobina Rehn, 1943 & Hispaniola & Rehn (1943) \\
\hline \multicolumn{3}{|l|}{ Genus Tainacanthus n. g. } \\
\hline Tainacanthus ferox $\mathbf{n} . \mathbf{s p}$. & Hispaniola & This work \\
\hline \multicolumn{3}{|l|}{ Genus Polyancistroides Rehn, 1901} \\
\hline Polyancistroides carcinus Rehn, 1937 & Cuba & Rehn (1937) \\
\hline Polyancistroides xanthicles Rehn, 1937 & Cuba & Rehn (1937) \\
\hline Polyancistroides gundlachii (Bólivar, 1884) & Cuba & Rehn (1937) \\
\hline
\end{tabular}

\section{MATERIALS AND METHODS}

From 2002-2004 we carried out a project to survey the Hispaniolan orthopteroid insects of the Dominican Republic. A total of 280 localities covering a large portion of the Dominican geography were sampled. These collections afforded two opportunities to visit the highest central mountains in which specimens of Tainacanthus were collected. Katydids were located tracking their intermittent songs and were collected with the help of an entomological net. For better preservation, the abdominal contents of the first series of specimens were taken out and their abdomens refilled with small pieces of napkins. Specimens of the second series were not gutted, as this did not appear to be necessary for good preservation. The stridulatory apparatus was examined in a comparative manner by partially dismembering one male and one female of each genus of Hispaniolan Polyancistrini. 
Photographs were taken using the Visionary Digital (TM) BK Lab imaging system outfitted with a Canon Mark II 5D. Scanning electron micrographs (SEMs) were obtained using a Hitachi TM 3000 microscope. For improved conductivity and better SEM imaging of the specimens, these were coated with a thin layer of gold/palladium alloy.

Body measurements (except for the interocular distance measured with a scale under a stereoscope) were made using a digital fractional caliper with resolution to $0.01 \mathrm{~mm}$. The body and pronotum length were measured on the dorsal midline, while the hind femur and tibia length were measured along the side. Locality data are given as they appear on the labels. In our project labels, the designation RD-046 represented the locality number [i.e., República Dominicana - \#046].

\section{Specimen depositories}

ANSP - Academy of Natural Sciences, Philadelphia, Pennsylvania. IIBZ- Instituto de Investigaciones Botánicas y Zoológicas, Universidad Autónoma de Santo Domingo, Dominican Republic. MNHNSD- Museo Nacional de Historia Natural, Santo Domingo, Dominican Republic. MSUC- Montana State University Collection, Bozeman, Montana. USNM- United States National Museum of Natural History, Smithsonian Institution, Washington, D.C.

\section{RESULTS \\ Taxonomy \\ Family Tettigoniidae Krauss, 1902 \\ Subfamily Pseudophyllinae Burmeister, 1838 \\ Tribe Polyancistrini Brunner von Wattenwyl, 1878 \\ Tainacanthus Perez-Gelabert, gen. nov.}

(Figs. 1-30)

Diagnosis. Distinguished from its apparent closest relative (Polyancistrus) by both sexes having a larger pronotum which is heavily armed around its margins by few, sharp and strong spines; legs with femora armed with spines only ventrally. Female ovipositor a short and relatively thick sword that curves gently upwards and tapers to a fine tip. The coloration of both sexes is a combination of light/dark brown and camouflage green. This coloration is unique to Tainacanthus, as Polyancistrus and Spelaeala are most commonly reddish brown and less often dark green. Some individuals of these last two genera show a combination of green and brown.

Diagnosis (In Spanish). Distinguible de su aparente pariente más cercano (Polyancistrus) por ambos sexos tener un pronoto grande el cual es fuertemente armado en sus márgenes por unas pocas espinas, agudas y fuertes; patas con fémures armados con espinas solo ventralmente. Ovipositor de la hembra una espadita corta y relativamente gruesa que curva suavemente hacia arriba y se hace angosta hasta terminar en punta fina. La coloración de ambos sexos es una combinación de castaño claro/oscuro y verde camuflaje. Esta coloración es única de Tainacanthus, ya que Polyancistrus y Spelaeala son más comúnmente castaño rojizo y menos frecuentemente verde oscuro. Algunos individuos machos de estos últimos dos géneros presentan una combinación de verde y castaño.

Description. See species description below.

Type species. Tainacanthus ferox Perez-Gelabert sp. nov., by original designation. 
Etymology. The generic name is in honor of the Taino natives of Hispaniola and the Greater Antilles, combined with acanthus, a Latinized form of the Greek acanthos, meaning "thorny", an epithet referring to the spiny nature of these katydids. This generic name is masculine.

Distribution. Only known from the highest mountains of the Cordillera Central, Dominican Republic, Hispaniola.

\section{Tainacanthus ferox Perez-Gelabert, sp. nov.}

(Figs. 1-30)

Type material. HOLOTYPE: Male, DOMINICAN REPUBLIC RD-046 La Compartición, Parque Nacional Armando Bermúdez, La Vega Prov., 1902.246’N 7058.147'W, 17.vii.2002, D. Perez, B. Hierro, R. Bastardo. Deposited at USNM entomological collection with catalog number USNMENT 01563335.

Coloration. Body color a combination of dark and light brown and camouflage green; integument not shiny but a buff brown. Epimera lighter brown than surrounding areas; dorsal surfaces of legs and abdomen cream or light brown. Outer borders of tegminae marked by a cream yellowish flattened area that is also markedly veiny. All spines on hind tibiae light brown or more rarely light green.

\section{Morphology}

Both sexes robust, medium-sized katydids $(28-32 \mathrm{~mm})$, brachypterous, and characteristically armed with strong, sharp spines on pronotum, dorsal abdominal midline and legs (Figs. 1-4).

Head. Rounded, relatively small, with small globular eyes; head vertex not elevated above pronotum, with fastigium of vertex not produced forward of eyes. Face relatively flat and smooth (Fig. 5). Antennae about 1.5X the body length and bearing a spine on its proximal article. This spine is more developed in Polyancistrus and Spelaeala.

Thorax. Pronotum a large thickened shield extended over and completely covering the remnants of tegminae; its margins armed with few (8), sharp and strong spines that are curved down or to the sides (middle anterior spines extend up, while the two flanking spines extend out) (Fig. 11). Prosternum, mesosternum and metasternum strongly developed, each armed with short and sharp spiny corners (Fig. 10).

Wings. Tegminae scale-like or lobate, less than half the length of pronotum and inflated into a bulbous dome that covers the stridulatory apparatus. This dome is slightly less bulbous in females. Small remnants of the membranous wings are present under the tegminae.

Abdomen. Globose in outline in both sexes. Male dorsal abdominal midline marked by small spines that grow on distal end of each tergum; these spines are noticeably longer and sharper in females. Margin of $10^{\text {th }}$ tergite deeply emarginated (Fig. 6).

Legs. Strong, more robust in males than in females; anterior, middle and posterior femora armed only on ventral margins; all tibiae armed with long and strong spines on internal, external and ventral margins. Tympanal openings very similar in both sexes, located near the top $1 / 5$ of the tibiae, the opening elliptical, rounded at top and closing at the bottom.

External genitalia. Epiproct triangular. Male cerci simple and relatively small, with one small apical tooth (Fig. 6). Margin of tenth tergite with marked concavity; male subgenital plate with v-shaped incision and short styli (Fig. 7). Female ovipositor a short thick sword that gently 
curves upward and tapers into a sharp point, its length just about half the length of abdomen (Figs. 2, 4, 9). This ovipositor morphology corresponds to katydids that lay their eggs within bark crevices (Gwynne, 2001).

Stridulatory apparatus. (Figs. 21-28) Both sexes of Polyancistrini katydids produce sounds. The sound production mechanism differs between the sexes, males have one stridulatory file located under the left tegmen made of about 80 teeth (Figs. 21-22), while females have a "stridulatory file" located dorsally on each tegmina (Figs. 23-24), consisting of a series of over 60 sclerotized pegs in each tegmina. Electron micrographs show the detailed structure of the stridulatory pegs in both sexes; those of the males are thickened and somewhat flattened teeth (Figs. 25-26), while those of the females appear as small spiny denticles with differences between the left and right sides (Figs. 27-28). Examination of individuals of both sexes in various species of Hispaniolan Polyancistrus and Spelaeala showed that they also have a similar mechanism for sound production in both sexes.

Song. The song of male Tainacanthus can be described as three (sometimes two) short and not very loud notes that are repeated intermittently every few seconds. These songs are relatively weak though it is possible to hear them from over 30 meters away. This is different from the species of Polyancistrus, for example, P. serrulatus, which can produce very loud calls which are repeated every few seconds.

Other material examined. ALLOTYPE: Same data as holotype, with catalog number USNMENT 01563336. PARATYPES: 12 males 5 females and 3 juvenile males, same data as holotype (ANSP, USNM, MNHNSD, IIBZ). 15 males 9 females, DOMINICAN REPUBLIC RD-254 La Compartición, P[arque] N[acional] Armando Bermúdez, La Vega Prov., 2,450 m, 1-2. vii.2004, D. Perez (d[ay]/n[ight]) (USNM, ANSP, NMNH, MHND, IIBZ). 1 female, DOMIN. [ICAN] REP.[UBLIC] Santiago, Par.[que] Nac.[ional] Armando Bermudez N.[orth] slope of La Pelona 09 July 1992, sweeping veg 2425 m, M. A. \& R. O. Ivie (MSUC). 2 males, same locality as type, but 04/xi/2012, cols. D. Perez, C. Ramírez (IIBZ).

Measurements (in mm). 5 males: BL (Body length: Head to end of abdomen) Mean $=28.66$, range $=27.69-32.20 ;$ PL $($ Pronotum length $):$ Mean $=15.73$, range $=15.05-16.55$; HFL (Hind femur length): Mean =17.36, range = 16.59-18.35; TI (Tibia length): Mean = 20.50, range $=19.59-21.91$. 5 females: $\mathrm{BL}$ (Body length): Mean $=29.92$, range $=25.69$ -33.03; PL (Pronotum length): Mean $=15.66$, range $=15.08-16.32$; HFL (Hind femur length): Mean $=17.89$, range $=16.14-18.91 ;$ TI $($ Tibia length $):$ Mean $=21.02$, range $=20.63-21.71$; OVI (Ovipositor length): Mean $=12.64$, range $=12.27-13.03$.

Etymology. Ferox, referring to the threatening appearance given by the spiny armature of these katydids. In fact, they are very shy and gentle insects with slow deliberate movements. Their main defense strategy when threatened is to drop from their perch and try to be invisible among the underbrush.

Habitat. The flora and vegetation of the Pico Duarte area was characterized by Zanoni (1993). The area of La Compartición is located at 2,450 $\mathrm{m}$ above sea level. At this high elevation, the vegetation is pine forest (Pinus occidentalis Sw.) interspersed with a lower stratus of hard evergreen shrubs, commonly Myrica picardae Krug \& Urb. (Myricaceae), Lyonia heptamera (Ericaceae), the bunch grass (Danthonia domingensis Hack. \& Pilg.) (Poaceae), ferns and lichens (Figs. 29-30). Other shrubs characteristic of the understory are Myrsine coriacea (Sw.) (Myrsinaceae), Ilex tuerkheimii Loes (Aquifoliaceae), Baccharis myrsinites (Lam.) (Asteraceae) and Garrya fadyeni Hook (Garryaceae). 

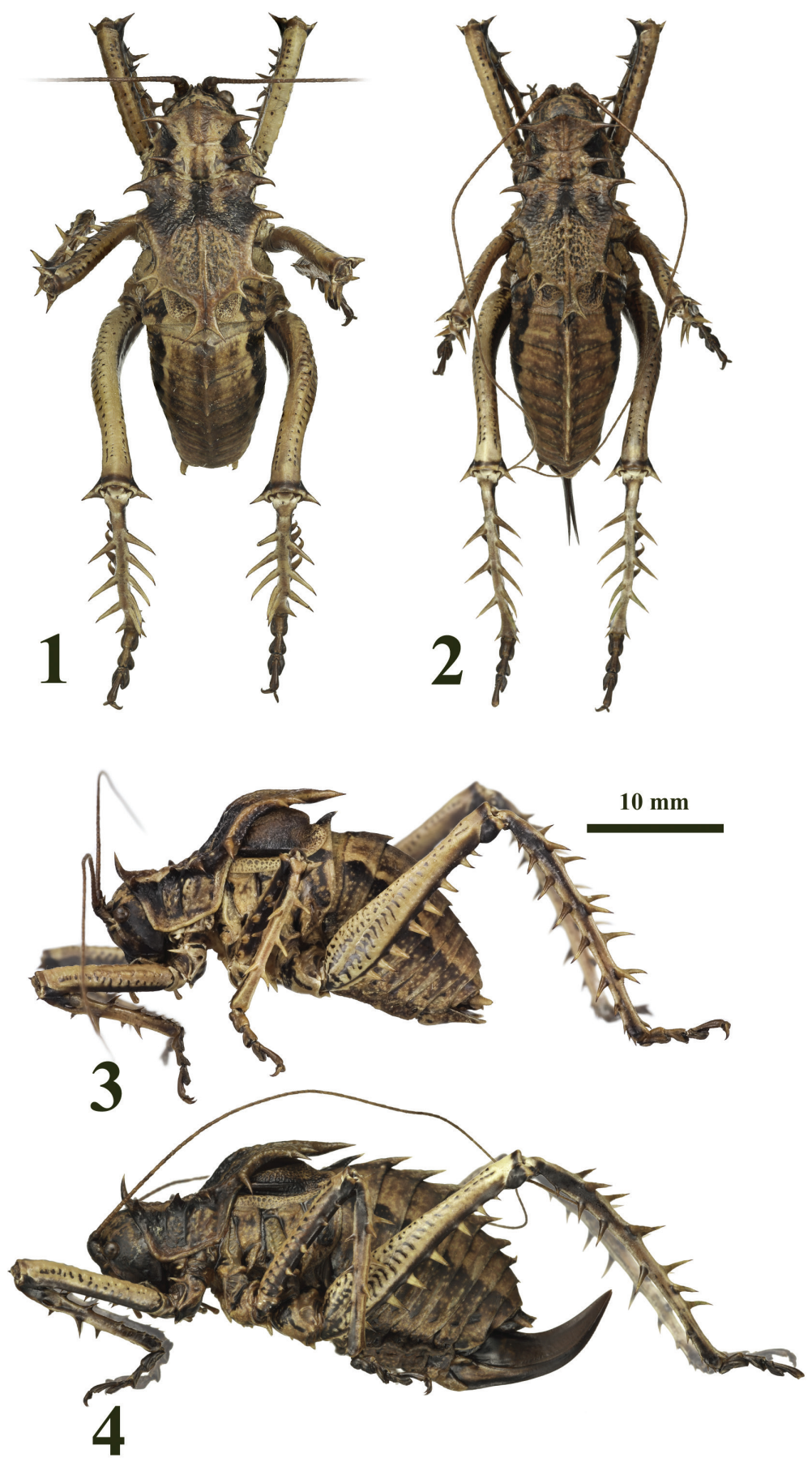

Figures 1-4. Habitus pictures of Tainacanthus ferox gen. nov., sp. nov. 1, male (dorsal). 2, female (dorsal). 3, male (lateral). 4 , female (lateral). 

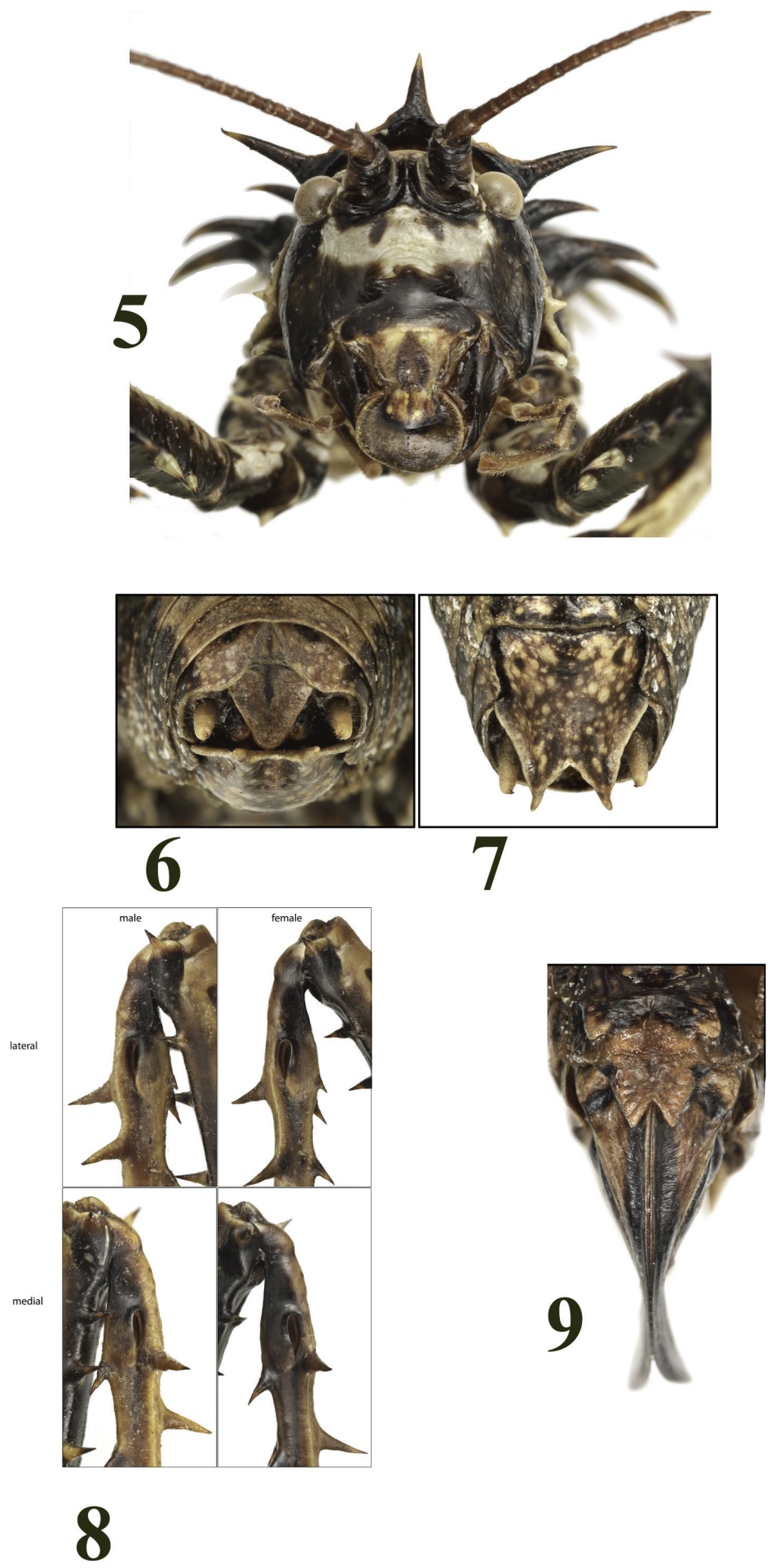

Figures 5-9. Morphology of several body parts of Tainacanthus ferox gen. nov., sp. nov. 5, face of male. 6, male abdominal end. 7, male subgenital plate (ventral). 8, male and female tympana on forelegs (lateral and medial views). 9, female subgenital plate and ovipositor (ventral). 


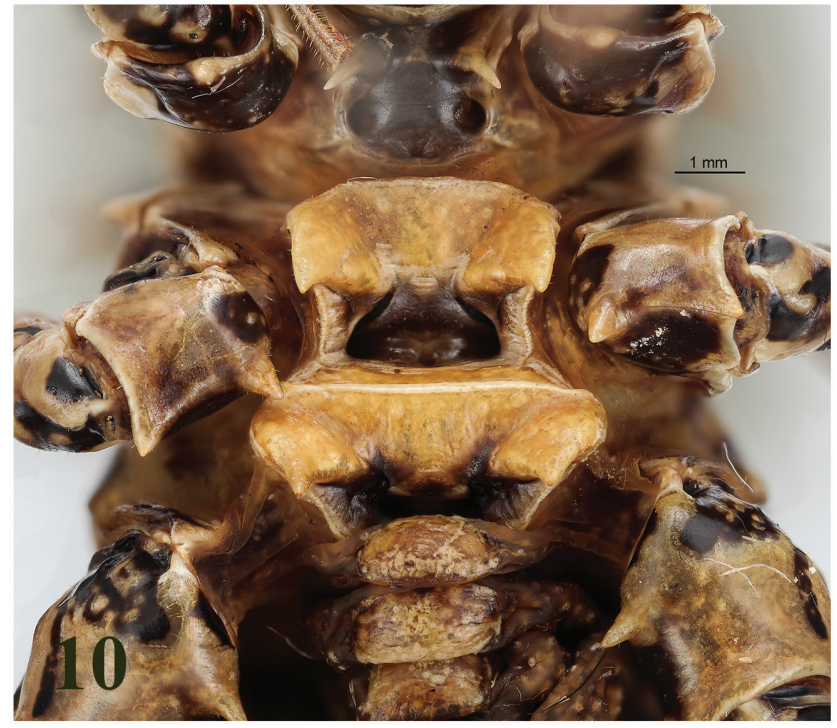

Figure 10. Morphology of the thorax (ventrally) Tainacanthus ferox gen. nov., sp. nov.

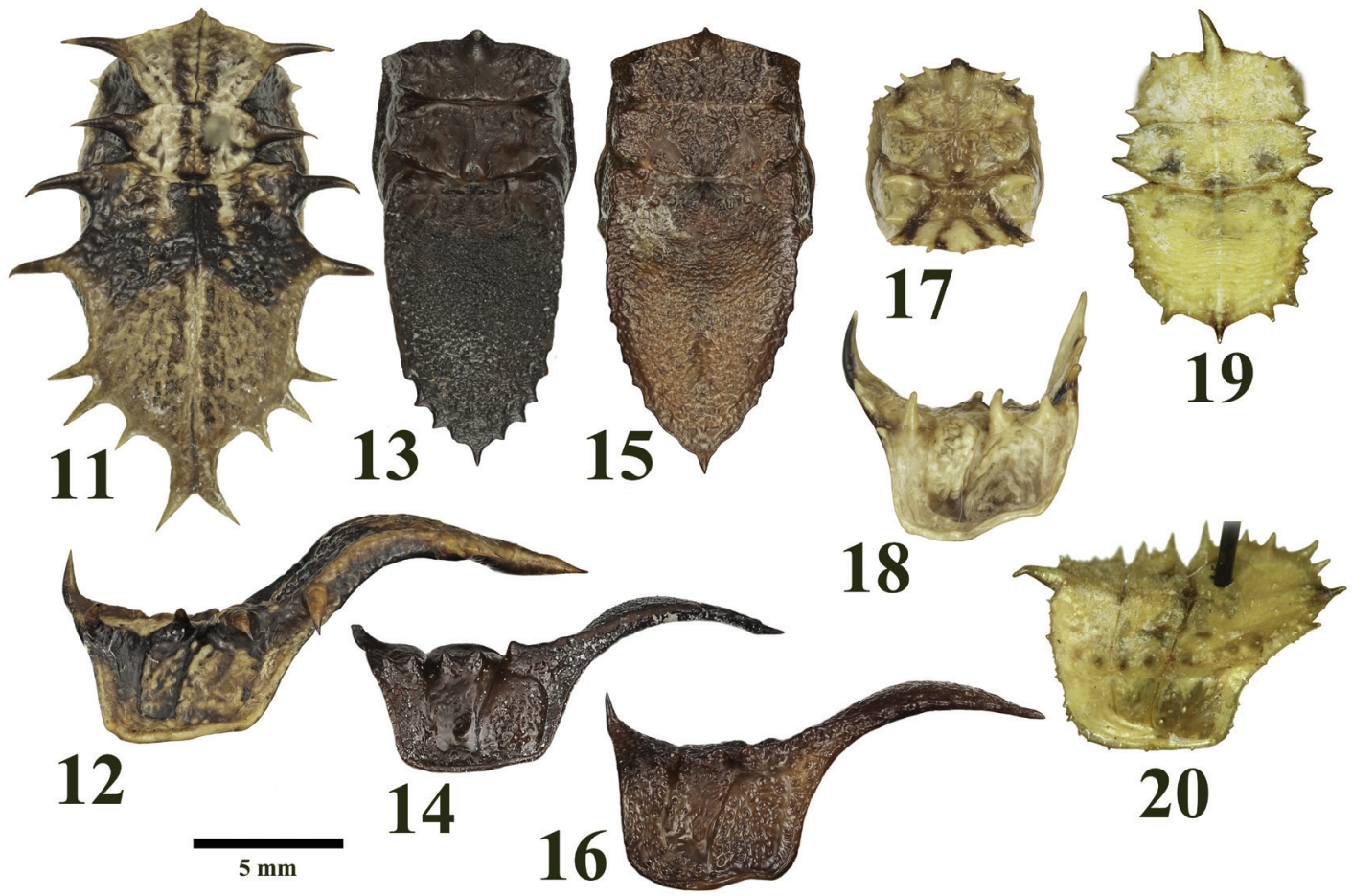

Figures 11-20. Comparison of pronotal morphology across the genera of Caribbean Polyancistrini (dorsal and lateral views). 11 and 12, Tainacanthus gen. nov. 13-16, Polyancistrus. 17-18, Spelaeala. 19-20, Polyancistroides. 

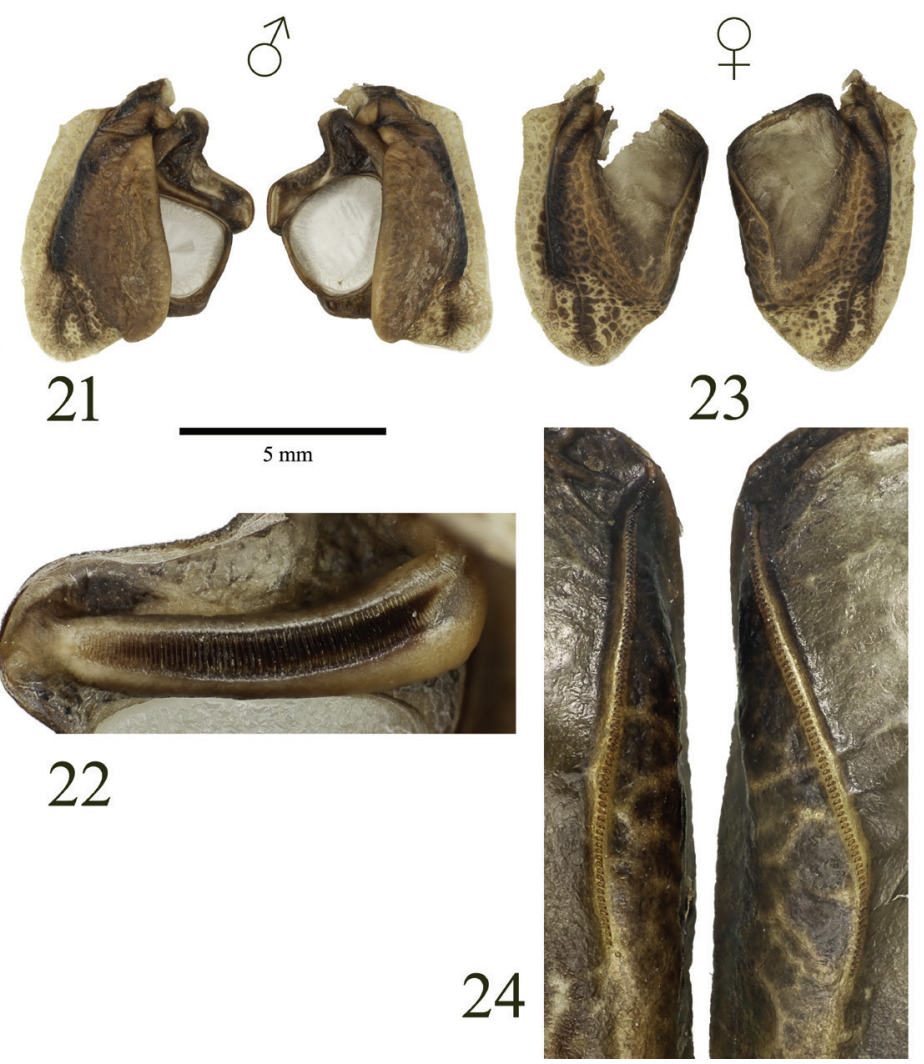

Figures 21-24. Stridulatory apparatus in both sexes of Tainacanthus ferox gen. nov., sp. nov. 21, right and left tegmen of male, 22 , detail of the male stridulatory file. 23 , eight and left tegmen of female. 24 , detail of the female stridulatory apparatus in the anal field of both wings.
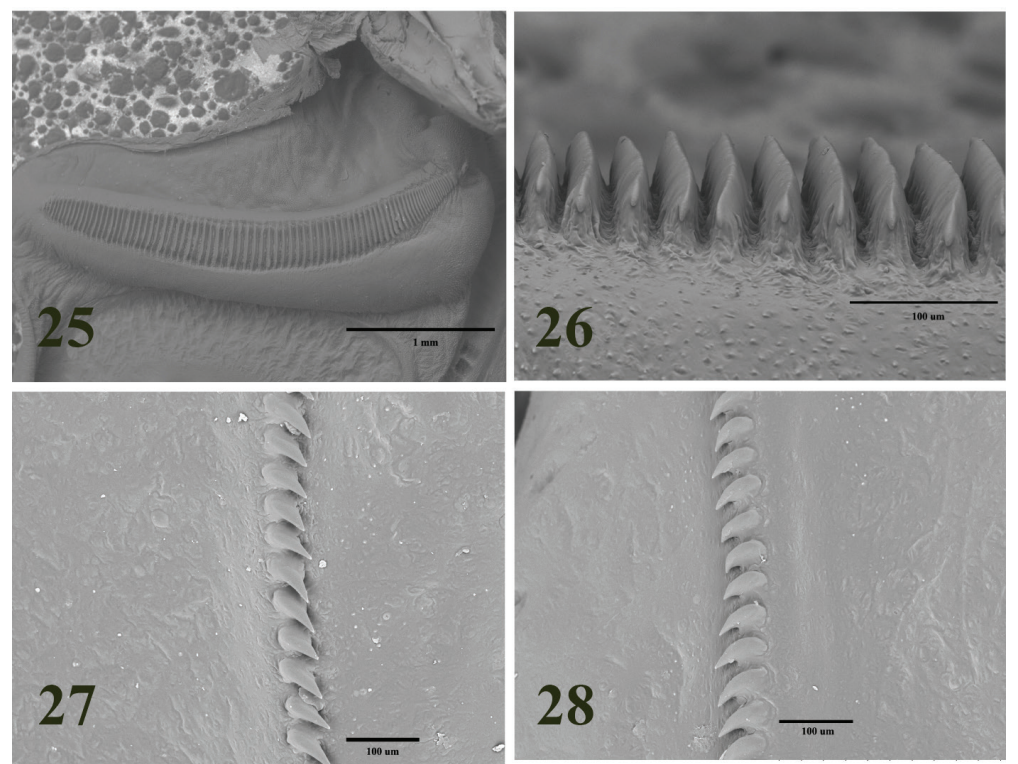

Figures 25-28. SEM of male and female stridulatory structures of Tainacanthus ferox gen. nov., sp. nov. 25, stridulatory file located under right tegmen. 26, detail of some stridulatory teeth in the male file under high magnification. 27 and 28 , detail of female stridulatory teeth on left and right tegmens. 

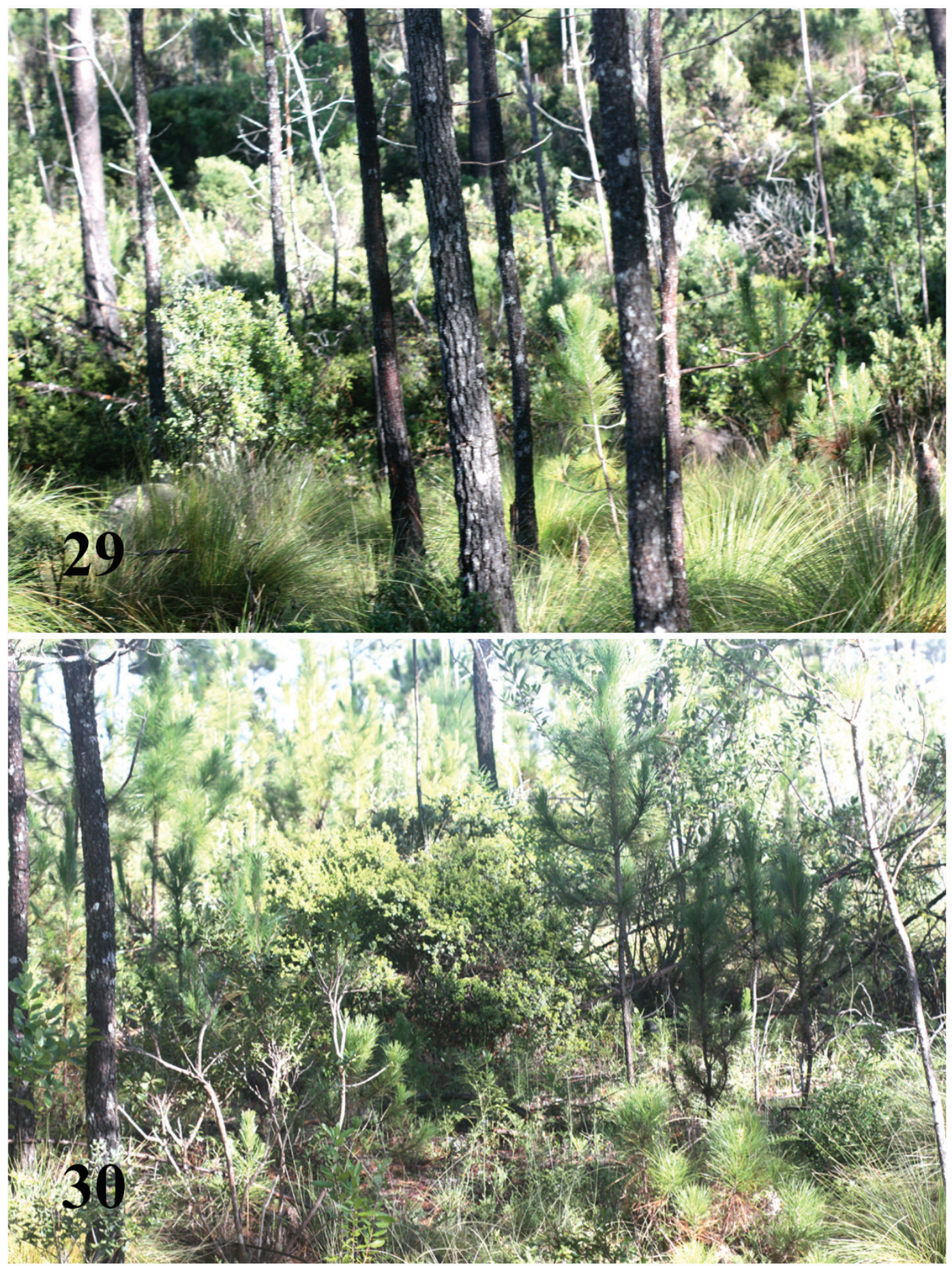
At night katydids persistently called from protected sites within the shrubs always perched at heights of less than two meters above the ground, becoming silent when approached. One of the main physical features of this environment are the cold temperatures typical of these high elevations in Hispaniola. Nights can be very cold and winter temperatures can reach $0{ }^{\circ} \mathrm{C}$. Among the parasites of pseudophyllines in Hispaniola, Perez-Gelabert and Grogan (1999) documented the ceratopogonid (Diptera) Forcipomyia (Microhelea) tettigonaris Wirth and Castner, as a sporadic ectoparasite of juvenile Polyancistrus and Spelaeala at two lower elevation sites of the Cordillera Central. The same parasitism was later observed on a juvenile Polyancistrus in Sierra de Bahoruco. Juvenile individuals which have a softer integument are always the ones affected with this parasitism. Other possible predators of these katydids are birds and bats, but their populations at high elevations are likely to be much smaller than at lower areas. Probably the current biggest predation threat to these katydids are the rats (Rattus rattus L.) that have followed human visitors and their food up these mountains. Sikes and Ivie (1995) reported the probable predation by rats of the endemic butterfly Anetia briarea at aggregation sites in the Pico Duarte area. No rats were seen at the park quarters of La Compartición during a first visit to Pico Duarte in 1987, but these were an obvious nuisance at the shelter in the 1990's and 2000's.

\section{KEY TO THE GENERA OF WEST INDIAN POLYANCISTRINI (BOTH SEXES)}

1A. Pronotum relatively small, saddle-shaped surrounded by small spines with metazona not much extended caudad over the tegminae (stridulatory apparatus). Figures 17-18. Dorsal surface of anterior femora with several rows of spines.......................................Spelaeala

1B. Pronotum relatively large, saddle-shaped with metazona markedly extended caudad over the tegminae (stridulatory apparatus). Dorsal surface of anterior femora without spines.......... 2

2A. Metazona not much developed and not bulbous, remnants of tegminae not covered by the pronotum (Figs. 19-20). Distributed in Cuba ................................Polyancistroides

2B. Metazona well-developed and markedly bulbous, remnants of tegminae covered by the pronotum. Distributed in Hispaniola ................................................... 3

3A. Pronotal margins marked by many small denticles (Figs. 13, 15)............. Polyancistrus

3B. Pronotal margins marked by few but large and sharp spines (Fig. 11)....

Tainacanthus gen. nov.

\section{DISCUSSION}

The general shape and size of the pronotum in Tainacanthus appears most like that of Polyancistrus, suggesting that it may be its closest relative. Spelaeala and the Cuban Polyancistroides share the feature of a metazona that is not much extended backwards (Figs. 17-20). Future work will review the taxonomy of both Polyancistrus and Spelaeala additionally incorporating molecular data.

The evolutionary history of the Polyancistrini katydids is likely as complex as the geological history of the Caribbean landmasses in which they evolved. Having relatively isolated extant representatives in Mexico, Ecuador and Brazil, besides those in the Greater Antilles, indicates that the group probably had a greater diversity and wider geographic range in the past than at present. An ancestor Polyancistrini likely colonized the islands from Central or South America early 
in the evolution of the Antillean archipelago. The island environment may have provided a refugium for these katydids, which free from the likely stronger competition and predation pressures experienced in the continent, eventually evolved into three genera in Hispaniola. The Greater Antilles as islands and Antillean faunal lineages are thought to be younger than Middle Eocene (about 35 million years old) (Iturralde-Vinent \& MacPhee, 1999). The early terrestrial connection of northern Hispaniola to eastern Cuba during the Miocene must have led to the expansion of Polyancistrini into that island and the evolution of the Cuban genus Polyancistroides. A more detailed comparative study and a molecular phylogeny of the Polyancistrini would reveal the relationships within the Caribbean genera, the relationships to their relatives in the continental areas and possibly important details about the evolutionary history of the group.

The phenomenon of female to male communication via sounds in katydids does not seem to have been much explored although it appears to be common among pseudophyllines (Gwynne, 2001). This occurs in the Hispaniolan Polyancistrini and it is a phenomenon that deserves more attention.

The katydid fauna of Hispaniola is still not well-known. The checklist of Hispaniolan arthropods (Perez-Gelabert, 2008) included 22 species of Tettigoniidae classified into four subfamilies (Conocephalinae, Meconematinae, Phaneropterinae and Pseudophyllinae). Two additional species, Erechthis gundlachi Bolívar, a species shared with Cuba and Pyrgocorypha uncinata (Harris), also found in Cuba and the eastern United States, were among the last additions to the katydid fauna (Perez-Gelabert, 2014). The species Erechthis ayiti (De Luca \& Morris, 2016), was later described from Haiti and the Dominican Republic. Most recently, Yong (2019) added two other species from Dominican Republic. Thus, including Tainacanthus ferox gen. nov., sp. nov. only 28 species of Tettigoniidae have so far been recorded from Hispaniola, although the finding of several additional undescribed genera and species already shows that this fauna is much more diverse. Despite the extensive damage to the forests of Haiti, additional katydids will also be discovered in Haiti, where very few Orthoptera specimens have been collected. Targeted efforts are necessary to obtain specimens and characterize these rare taxa.

\section{ACKNOWLEDGEMENTS}

I wish to express my gratitude to Michael A. Ivie (Montana State University, Bozeman) who loaned me the first specimen of Tainacanthus, thus revealing the existence of these remarkable katydids. In Santo Domingo, biologists Brígido Hierro and Denia Veloz (Ministerio de Medio Ambiente y Recursos Naturales), Ruth Bastardo (Instituto de Investigaciones Botánicas y Zoológicas), and Sardis Medrano (Instituto Dominicano de Investigaciones Agropecuarias y Forestales) participated of the Hispaniolan Orthopteroids Project contributing with field work, laboratory assistance and companionship during many arduous days in the field. I am also grateful to Daniel Otte (Academy of Natural Sciences of Philadelphia) for access to the Academy collection and for pictures of Polyancistroides. Karolyn Darrow (National Museum of Natural History, Smithsonian Institution) expertly produced the specimen pictures. Scott Whittaker (National Museum of Natural History, Smithsonian Institution) assisted with the SEM images. Brígido Peguero (Jardín Botánico Nacional, Santo Domingo) and Ruth Bastardo helped with botanical data, especially the identification of the plant Myricae picardae. Fieldwork during the Orthopteroids Project in the Dominican Republic was made possible by funds of the National Science Foundation project DEB-0103042. 


\section{LITERATURE CITED}

Audinet-Serville, J. G. 1831. Revue méthodique des insectes de l'ordre des orthoptères. Annales des Sciences Naturelles, 22: 134-167.

Bruner, L. 1915. Notes on tropical American Tettigonioidea (Locustodea). Annals of the Carnegie Museum, 9: 284-404.

Cigliano, M. M., H. Brown, D. C. Eades, \& D. Otte, 2018. Orthoptera Species File online (OSF). Version 5.0/5.0. Available from: http://orthoptera.speciesfile.org/HomePage/Orthoptera/ HomePage.aspx. (Accessed: January 2018).

De Luca, P. A. \& K. G. Morris. 2016. Erechthis katydids (Tettigoniidae: Conocephalinae) in the Caribbean: new species from The Bahamas and Hispaniola. Journal of Orthoptera Research, 25: 49-59.

Gwynne, D. T. 2001. Katydids \& Bush-Crickets: Reproductive Behavior and Evolution of the Tettigoniidae. Cornell University Press, Ithaca, 317 pp.

Iturralde-Vinent, M. A. \& R. D. E. MacPhee. 1999. Paleogeography of the Caribbean Region: implications for Cenozoic biogeography. Bulletin of the American Museum of Natural History, 238: 1-95.

Naskrecki, P. \& C. Lopes-Andrade. 2005. A new genus and species of katydids of the tribe Polyancistrini (Orthoptera: Tettigoniidae: Pseudophyllinae) from Brazil, an apparent pest of Eucalyptus plantations. Zootaxa, 952: 1-8.

Palisot de Beauvois, A. M. F. J. 1805. Insectes Recueillis en Afrique et en Amérique, dans les royaumes d'Oware et de Benin, a Saint-Domingue et dans les Etats-Unis, pendant les années 1786-1797. Imprimerie de Fain et Cie., 276 pp., 90 pls.

Perez-Gelabert, D. E. 2008. Arthropods of Hispaniola (Dominican Republic and Haiti): a checklist and bibliography. Zootaxa, 1831: 1-530.

Perez-Gelabert, D. E. 2014. Two new records of katydids (Orthoptera: Tettigoniidae: Conocephalinae) from the Dominican Republic, Hispaniola. Novitates Caribaea, 7: 28-36.

Perez-Gelabert, D. E. \& W. L. Grogan, Jr. 1999. Forcipomyia (Microhelea) tettigonaris (Diptera: Ceratopogonidae) parasitizing katydids (Orthoptera: Tettigoniidae) in the Dominican Republic. Entomological News, 110: 311-314.

Rehn, J. A. G. 1936. The Hispaniolan genus Polyancistrus (Orthoptera, Tettigoniidae, Pseudophyllinae). Transactions of the American Entomological Society, 62: 271-316.

Rehn, J. A. G. 1937. The Cuban genus Polyancistroides (Orthoptera: Tettigoniidae, Pseudophyllinae). Transactions of the American Entomological Society, 63: 333-345.

Rehn, J. A. G. 1943. A new genus and two new species of Hispaniolan Pseudophyllinae (Orthoptera: Tettigoniidae). Notulae Naturae, 125: 1-14.

Sikes, D. S. \& M. A. Ivie. 1995. Predation of Anetia briarea Godart (Nymphalidae: Danainae) at aggregation sites: A potential threat to the survival of a rare montane butterfly in the Dominican Republic. Journal of the Lepidopterists'Society, 49: 223-233. 
Yong, S. 2019. Three new genera and four new species of katydids (Orthoptera: Tettigoniidae) from Cuba and Hispaniola, Greater Antilles. Ecologica Montenegrina, 20: 222-256.

Zanoni, T. A. 1993. La flora y la vegetación del Pico Duarte y la Loma La Pelona, República Dominicana. Moscosoa, 7: 1-14.

[Recibido: 28 de junio, 2019. Aceptado para publicación: 10 de octubre, 2019] 